Portland State University

PDXScholar

1974

\title{
Designing and Evaluating Workshop "Bridges": a Training Project to Upgrade Social Services in Long Term Care Facilities
}

Corrine C. Williams

Portland State University

Follow this and additional works at: https://pdxscholar.library.pdx.edu/open_access_etds

Part of the Gerontology Commons, Social Welfare Commons, and the Social Work Commons Let us know how access to this document benefits you.

Recommended Citation

Williams, Corrine C., "Designing and Evaluating Workshop "Bridges": a Training Project to Upgrade Social Services in Long Term Care Facilities" (1974). Dissertations and Theses. Paper 1759.

https://doi.org/10.15760/etd.1758

This Thesis is brought to you for free and open access. It has been accepted for inclusion in Dissertations and Theses by an authorized administrator of PDXScholar. Please contact us if we can make this document more accessible: pdxscholar@pdx.edu. 
DESIGNING AND EVALUATING WORKSHOP "BRIDGES":

A TRAINING PROJECT TO UTPRADE SOCTAI. SERVTCES

IN IONG TERM CARE FACIITTRIES

by

CORRINNE C. WILLIAMS

A practicum submitted in partial fulfillment of the requirements for thi legree of.

MA.STER

of

SOCTAL' WORY.

PortIand State University

1.974. 
TABLE OF CONTENTS

PAGE

IIST OF TABLES. • . . . . . . . . . . . . . . iv

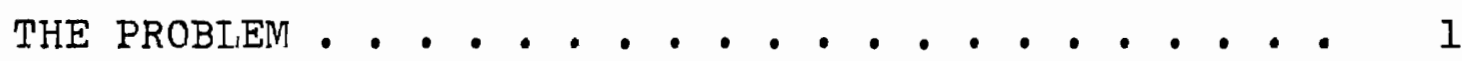
BACKGROUND. • . . . . . . . . . . . . . . 2 THE SETTING • • • . . . . . . . . . . . . . 4 PROGRAM COMPONENTS. • . . . . . . . . . . . . 7 EDUCATIONAL METHODS . . . . . . . . . . . . . 8 EVALUATION DESIGN • • • • • • • • • • • • • . 9 TABIES AND FINDINGS • • • . • . • • • . • • . 11 CONCLUSTONS AND IMPLICATIONS. • • • • • • • • • 26


APPENDICES. . . . . . . . . . . . . . . . 34 Program . . . . . . . . . . . . 34 Evaluation Form 1 . . . . . . . . . $40^{\circ}$ Evaluation Form 2. . . . . . . . . 43 Evaluation Form 3. . . . . . . . . 46 


\section{LIST OF TABLES}

T. BI:E

1 Modal Responses of' Four Groups on Self Rating of Capabilities in Five Areas "f Frpertise

2. Modal Responses of Four Grnups to Now Learning. from 0 (none) to $4(m u n)$. . . . . 26

3 Moda] Responses of Fnur Groups to Questions About Progrim and Ratiness of Days. . . . 18

4 Averaged Modal Effects, from 0 (none) to 4 (much) of Teaching Methods by nccupation Class. . 20

5 Unweirghted Means of Modal. Ratings of Effects of Teaching Methods, All Ccounation Classes Grouped Together . . . . . . . . 22

6 Number of Different Improvements in Specified Skill Areas by occupational Class. . . . 24 
THE PROBLEM

Early in the fall of 1.973, the Oregon Chapter of the National Association of Socia]. Workers (N.SW) decided to sponsor a statewide training project in cooperation with seven chapters in other Department of Health, Education and Welfare (DHEW) regions across the United States. These workshops were to comprise Stage I of a two-stage plan; they were to serve as demonstration projects. Their planning, implementation and evaluation were to be seriously reviewed and studied afterward in an attempt to devise a model, or models, for stage II, when a great number of such workshops would be held acrọs the nation. The training plan ensued as part of a contract between NASU and the Health Resource Administration of DHEW, and was entitled Project Provide.

The purpose of the contract was to train social work designees and consultants who are employed in Iong Term Care Facilities (ITCF). The objective of the training was to initiate and/or improve appropriate social services to reduce the unmet social and human needs of residents and their famjlies. The problem was two-fold: first, how to design such a training project to make the best use of very ljmited resources and yet be relevant to the state of social service practice in oregon's iTCFs; and second; how to evaluate the learning that took place and teanhing modes used. 


\section{BACKGROUND}

Nursing homes, used symonvmously with the term IJCF" in this paper, are relatively new as a widespread phenomenon in the United States. Despite the Social Security Act of 1935. which provided federal matching funds for non-institutional cash assistance grants, matching funds to states for assistance to persons residing in public institutions were prohibited. Not until 1.950 was the ban lifted on payment to public institutions. In 1956, the federa? government amended the Social Security Act to assist the states in medical care for recipients, including nursing home care. After Medicare and Medicaid was passed in 1965, Titles 18 and 19 of the 1965 Amendment provided health insurance benefits for post-hospital extended care. Subsequent amendments have defined levels of care, provided for utilization review and generally upgraded the provision of care in ITCF日.

Project Provined is the latest of a series of training programs for ITCF personnel. that have been funded by the Human Resources Administration of DHEW, growing out of national recognition of increased need and jressure for social services to impaired persons in such institutions. Research and experience in recent years have shown ways for restoring chronically impaired persons to functioning levels previousI.y thought impossible, with the accompanying reduction of 
mental disorders and death rates of such patients. 
THE SFT'TTNG

The training project in oregon was organjzed through an Ad Hoc Committee, which selected a coordinator/facilitator. In the initial planning, the latter was advised ard quided by a Steering Committe comprised of NASW members, representative of PSU School of Social Work and agencie: from the fields of gerontolngy, health, welfare, rehabilitation and government. The theme for the workshnp was Bridges, to symbolize the need for erasing harriers and developing an inter-discipl inary apprnarh in proviring services for residents of nursing homes.

The orisinal intent of Project Provide was, first, to improve the capabjlities of social service designees for delivering social services: in ITCFs, and to function more effectively as part of thr inter-discjplinary treatment team therein; and, second, for Sorial work Consultants to focus on sharpening their consultant skjIIs to ITCFs and their abiljties as staff trajners and supervisors of social service resignees.

Tt was noted at the first committee meeting that there were hardly any Nursing Home Consultants working in that capacity at this time in oregon since the requirement had been deleted at the ffderal lovel. A social service designee was defined as that penson primarily responsible 
for the social service with the ITCF. Such eould range from being a social worker, on a full- or part-time basis, performing only those services...to n nurse or a Director of Nurses, Activities Director or the Nursing Home Administrator who assumed that function along with other duties.

A decision was made to open the workshop to any nursing home staff interested in partjcipating, on the rationale that everyone there was involved to some degree in providing social services. It was thought particularly important to include Nursing Home Administrators in the target group, whether or not they served officially as social service designees. Such individuals must be convinced of the value of social services in order to promote them in the institution.

Concern was also expressed regarding the skills, knowledge and attitudes of other providers of social services outside the ITCF-- particularly the Public Welfare workers, called Adult Service workers in the agency's present organization, to participate in the training. Along with that group would be their supervisors; Volunteer Cocrdinators would provide the link between nursing home residents and the community in terms of volunteer services and programs. Also included in the target group were mental health workers because of their increasing involvement in consultative roles and program development for emotionally and/or developmentally disabled individuals for whom either full or 
part-time nursing home care could be a viable alternative as the state hospitals are phased out.

Hence, as the committee defined the target group, it was expanded beyond the original two groups to include all employed persons likely to provide consultatior. and social services to residents of LTCPs. This created edditional problems because of the diversity of the participants, but also enlarged the possjbilities of more intensely upgrading the care provided.

It was also recognized that this approach. increased the prospect of disagreement and tension between competitive agencies and interest groups (surh as exints between the proprietory and non-proprietory homes). The importance of training in an inter-disciplinary team approach provided the basis for taking the risks. 


\section{PROGRAM OCMPONENTS}

Decixing which areas of knowledge, attitudes and skills that should be focused upon involved setting priorities. An a.tempt was made to assess what was currently being done at a majority of the homes, and what was not being done but should be. It was recognized that the 32-hours of training was only going to deall with a limited number of topics in limited depth. The following areas were chosen:

(1) what it means to be an aging person;

(2) the team apprnaroh in nursing home care:

(3) sorjal components of nursine home care;

(4) menta]. retardation and developmental disablement;

(5) community and volunteer services;

(6) special topics, including protective services and psychotropic medicines.

The role of the consultant and the social service designee would be given particular atiention within the scope of these broad areas. 


\section{EDUCATTONA I: MFTHCDS}

A variety of teaching mothors were chose' to he ul ed in the workshon ror the nurnmsa of attempting to measur. both the impact of training, and the mos" effestive mod. of teachirg know] edse, attitudor and ri]ls in relation to the different occunational grounc hejng trained. Such methrds were: lectures, discussion'tpanol rrouns, a drimatic prosentation, simulation exernices, small grourns -- 'ooth strui tured and unstmaturea, and a danes domonstration: A requirement of the sriginal nlanning was trat thu trainin be as experiential as possible. Since the rarticipants were so diverse in both eduration and exprrifnce, the "im was to provide a medium level of knowlodro with opportunities tor partinipants to practice the thenrotical concents in numerous ways.

An attempt was liade a? sr to obtain the bert lecturers and skilled teachers availnble in the western part of the United States for the majcr areas of trajning. 


\section{EVAIUATION DESIGN}

At the beginning of the workshop, time was scheduled to explain the purpose and value of the evaluation forms, and time was allowed at the end of the day for their completion and collection.

The two models for evaluating the workshop are shown by Forms I through 3. On all forms, the participant was asked to check the occupational class to which he/she belonged, along with the proper data.

Forms 1 and 2, Parts II, are attempts to measure the impact on training (see Appendix). The participant was asked to mark his position on a continuum from weak to strong as he perceived his level of expertise in five different areas -- at the beginning of the workshop. The same effort was requested at the end, plus a number of other questioms assessing particular aspects of the training, with room for comments regarding the subject best taught, omissions, most important thing learned and general remarks. A coding system was used for Forms 1 and 2 so that a comparison could be made with regard to change or sameness on the student's part at the end of the training. Part I of Form 2.also provides for rating the workshop in terms of the acquisition of a number of new, specific items (scale A), and then of general reactions (scale $B$ ). 
Form 3 is the second model for evaluation. This f $\mathrm{rm}$ was passed out at the end of each day's session, and col'ected immediately. Ratings of the mode of teaching applicible to that day were requested, on a five-poirt scale from $z$ ro (none) to four (much) with regard to attitudes, knowled $\sigma_{\text {: }}$ : and skills. For the second day, students were asked, in addition, to specifiy any particular skill acquired or inproved that would change their way of working with peopl? from then on. 


\section{TABLES AND FINDINGS}

Out of 160 long evaluation forms (Forms l) given to registered, full-time participants at the beginning of the workshop, 149 were returned. Of the 140 questionaires given out at the end (Form 2) 130 were completed -- resulting in am $84 \%$ return. On the short evaluation form (Form 3 ) the number completed varied from day to days

$\begin{array}{ll}\text { Ist day: } 151 & \text { 3rd day: } 144 \\ \text { 2nd day: } 171 & \text { 4th day: } 118\end{array}$

Those attending on a part-time basis (any less than the four days) were allowed to fill out the short form, along with the full-time participants.

On the long evaluation forms, it appeared feasible to separate those results ints four different groups:

(1) staff members of nursing homes who ere responsible for the social services within the facility;

(2) staff members of the nursing homes who were not responsible for social servises within the facility;

(3) workers outside the nursing homes who were responsible for social services (at least $50 \%$ of thejr time) to clients in such facilities;

(4) workers outside nursing homes who were not directly responsible for social serrices in nursing homes. The variables for Forms $]$ and 2, Parts II, were men- 
sured on a continuum divided irto 12 aqua $:$ parts, ranging from 0 to 60 , with tal.7 ies nare around points midway in each category. $(2.5,5.0,7.5,10.0$, etc, , up'tc 57.5). 3eturns of Form 2, Part I ( $A$ and $B$ ), and Form 3, were tallied according. to the box checked. The short evaluation form; were separated according to days, and then into occupational classes, or positjons.

For all of the evaluation forms, the mode was used as the measure of central tendency. Given tre distribution of scores and the nature of the variation, the mode is a conservative measurement in this study. In r:ases where there was not a mode, a mean of the equin distributions was usad instead, and so noted with an asterisk.

Table 1 summarizes the results of Forms $I$ and 2, Parts II, in which the respondente are asked to place an $\mathrm{x}$ along the Iine tc represent the degree of expertise he/she feels he/she has initially in each of five areas of social service in nursing homes $z$ s described. (See Forms 1 and 2, Appendix.)

These areas are:

A. The Nursine Home *

B. Perceptions of Social Service

c. What It Means Tro Be An Aging Person

D. How to Meet the Needs of Aging Persons within the Institution 
TABLE 1

MODAL RESPONSES OF FOUR GROUPS ON SELF RATINGS OF CAPABILITIES IN FIVE AREAS OF EXPERTISE

\begin{tabular}{|c|c|c|c|c|}
\hline Areas of Expertise & $\operatorname{Group}^{1}$ & $\begin{array}{l}\text { Group } \\
\text { II } \\
\end{array}$ & $\begin{array}{l}\text { Group } \\
\text { III } \\
\end{array}$ & $\begin{array}{l}\text { Group } \\
\text { IV } \\
\end{array}$ \\
\hline $\begin{array}{l}\text { Question } A: \\
\text { Nursing Home } \\
\text { Before } \\
\text { After } \\
\text { Difference }\end{array}$ & $\begin{array}{l}27 \cdot 5 \\
37 \cdot 5 \\
10.0\end{array}$ & $\begin{array}{l}45.0 * \\
42.5 \\
-2.5\end{array}$ & $\begin{array}{c}42 \cdot 5 \\
42.5 \\
0\end{array}$ & $\begin{array}{l}12.5 \\
37 \cdot 5 \\
25.0\end{array}$ \\
\hline $\begin{array}{l}\text { Question B: } \\
\text { Social Services } \\
\text { Before } \\
\text { After } \\
\text { Difference }\end{array}$ & $\begin{array}{r}32.5 \\
37.5 \\
5.0\end{array}$ & $\begin{array}{l}32.5 \\
42.5 \\
10.0\end{array}$ & $\begin{array}{r}52.5 \\
42.5 \\
-10.5\end{array}$ & $\begin{array}{c}42.5 \\
42.5 \\
0\end{array}$ \\
\hline $\begin{array}{l}\text { Question C: } \\
\text { The Aging Person } \\
\text { Before } \\
\text { After } \\
\text { Difference }\end{array}$ & $\begin{array}{r}57.5 \\
42.5 \\
-15.5\end{array}$ & $\begin{array}{l}45 \cdot 0^{*} \\
42 \cdot 5 \\
72 \cdot 5\end{array}$ & $\begin{array}{l}42.5 \\
52.5 \\
10.0\end{array}$ & $\begin{array}{l}32.5 \\
42.5 \\
10.0\end{array}$ \\
\hline $\begin{array}{l}\text { Question D: } \\
\text { Meeting Needs in } \\
\text { Institution } \\
\text { Before } \\
\text { After } \\
\text { Difference }\end{array}$ & $\begin{array}{r}57 \cdot 5 \\
47.5 \\
-10.0\end{array}$ & $\begin{array}{l}50.0 * \\
45.0 * \\
-5.0\end{array}$ & $\begin{array}{r}37.5 * \\
42.5 \\
5.0\end{array}$ & $\begin{array}{l}32 \cdot 5 \\
47 \cdot 5 \\
15.0\end{array}$ \\
\hline $\begin{array}{l}\text { Question } E: \\
\text { Community Resources } \\
\text { Before } \\
\text { After } \\
\text { Difference }\end{array}$ & $\begin{array}{r}32.5 \\
37 \cdot 5 \\
5.0\end{array}$ & $\begin{array}{l}32.5 \\
27.5 \\
-5.0\end{array}$ & $\begin{array}{r}47.5 \\
35.0^{*} \\
-12.5\end{array}$ & $\begin{array}{r}32.5 \\
37.5 \\
5.0\end{array}$ \\
\hline
\end{tabular}

Notes: * Average of more than one mode

A minus sign $(-)$ indicates a lower modal estimate of expertise after workshop than

before

2 Nursing Home Staff giving social services

2 Nursing Home Staff not giving social services

3 outside staff giving social services

Outside staff not giving social services 
E. Resources Within the Community

The questionaires were separated into four groups, as noted earlier.

This form of evaluation is very subjective, and, in the first instance, the respondent's position may be taren without the realization that he/she may have the opportunity/ request to repeat the exercise later on, or without giving much thought or suspicion to the possibility of being exposed to considerable new horizons or depths of knowledge. Such explanations may account for the derrease (minus) in points or expertise indicated by one or more groups on every question.

Question A: The Nursing Home. It is interesting to note that Group \#3 initially had much stronger positions regarding expertise than djd Group \#.1, but not as high as Group \#2. The latter lost 2,5 points on the continuum in the end response, and Group \#1 gained 10 points. Group \#4, who were lowest to start with, came up to Group \#I in the end, gaining a total of 25 points.

Question B: Perceptions of Social Servise. Group \#3 placed themselves initially in the highest position of all, and lost 10 poin:s at the end. Group \#1 gained 5 pointr, 
and Group \#2 gained the most in expertise. Group \#4 gave themselves a relatively strong posit: on to start with, and gained nothing.

Question C: What It Means to Be An Aging Person. Here Group \#1 gave themselves very high ratings and lost 15.5 points in the training. Group \#2 were next in intial ratings, and lost 2.5 points. Workers outside the institution were lower to start with, and both such groups perceived big gains in the training.

Question B: How to Meet the Needs: of Aging Persons Within the Institution. The same disparity happened with this area. The groups within the nursing homes started out higher and lost points, while those workers outside made gains from more modest positions.

Question E: Resources Within the Community. Group \#3 started out highest and lost the most; Group \#2 lost some while the reamining two groups ties with modest gains.

Table 2 shows modal responses with respect to learning. by four groups, inside and outside the nursing home, giving or not giving social service. In comparing the responses of the four groups to rating of learning (Part I - A, Form 2), Group \#l gained more, and in different areas, than those 
TABT.E 2

MODAL RFSPONSES Or FOIR GROIPS TO NEW IEARNING FROM O (NOIE) to 4 (MUR H)

Question

\begin{tabular}{|c|c|c|c|}
\hline Group ${ }^{1}$ & $\begin{array}{c}\operatorname{crnup} \\
\mathrm{II} \\
\end{array}$ & $\begin{array}{c}\text { Group }^{3} \\
\text { III } \\
\end{array}$ & $\begin{array}{c}\text { Group } \\
\text { IV } \\
\end{array}$ \\
\hline$?$ & 2 & $2.5^{*}$ & 4 \\
\hline$?$ & 2 & 2 & 3 \\
\hline 2 & 2 & 2 & 2 \\
\hline 2 & 2 & 2 & $1.5 *$ \\
\hline 3 & 2 & 2 & 2 \\
\hline 3 & 2 & 2 & 2 \\
\hline 2 & 2 & 2 & 2 \\
\hline 2 & 2 & 1 & 2 \\
\hline 3 & 2 & 1 & 2 \\
\hline 2 & 2 & 2 & 2 \\
\hline 2 & 3 & $1.5^{*}$ & 3 \\
\hline 2 & 2 & 2 & 2. \\
\hline $2.5^{*}$ & 3 & 3 & 2 \\
\hline 2 & $\because$ & 2 & 2 \\
\hline
\end{tabular}

Notes: Questions:

1. New nsight!:

2. Hew understandings

3. New idfas

4. New skji? s

5. New motivations

6. Nev: ferlings

7. New melationships

8. Jiew rosources

9. New ways of using resources

10. New approaches

11. Jew confiderce

12. Renewind roinforcement:

13. New knowledge

14. More dotajled knowledge

* Average uf more than one mode

1 Nursing tome staff giving social services

3 Nursing Home staff not gjving social services

4 outside staff giving social services.

nutside staff not giring social services 
staff not responsib].e for social services in the institution. Group \#4 gained new learning to the same degree as \#l. The Iowest amount, among the folr groups, of new learning was among Group \#3: workers outside the institution providing social services. The only itrms which the latter group rated above 2 (the middle on the scale) were new insights and knowledge. Questions 8, 9 and 11 were scored below average. Perhaps these participants came to the training prnject more adequately educated and experienced than the others. Comparison of the responses of Group \#1 and \#4, although tying for highest total scores, varied in content noticeably. The outside staff not giving social service scored highest in new insights, understandings and confidence; Group \#I rated above average in the acquisition of new motivations, feelings and know]edge.

Table 3 of Evaluation Part I - B, Form 2, is concerned with general, overall evaluation of the training project. Again, the same four groups are used to rate, in questions 1 to 5, matters involving the workshop's design, scheduling and some basic premises affecting, target groups and goals. Group \#4 rated the workshop the highest, followed by Groups \#3 and \#2; Group \#I gave the Irwest score. Al1 groups 
TABIE 3

MODAI RESPONSES OF FOUR GROUPS TO QUESTIONS ABOUT PROGRAM FROM 0 (NONE) TO 4 (MUCH)

AND RATINGS OF DAYS

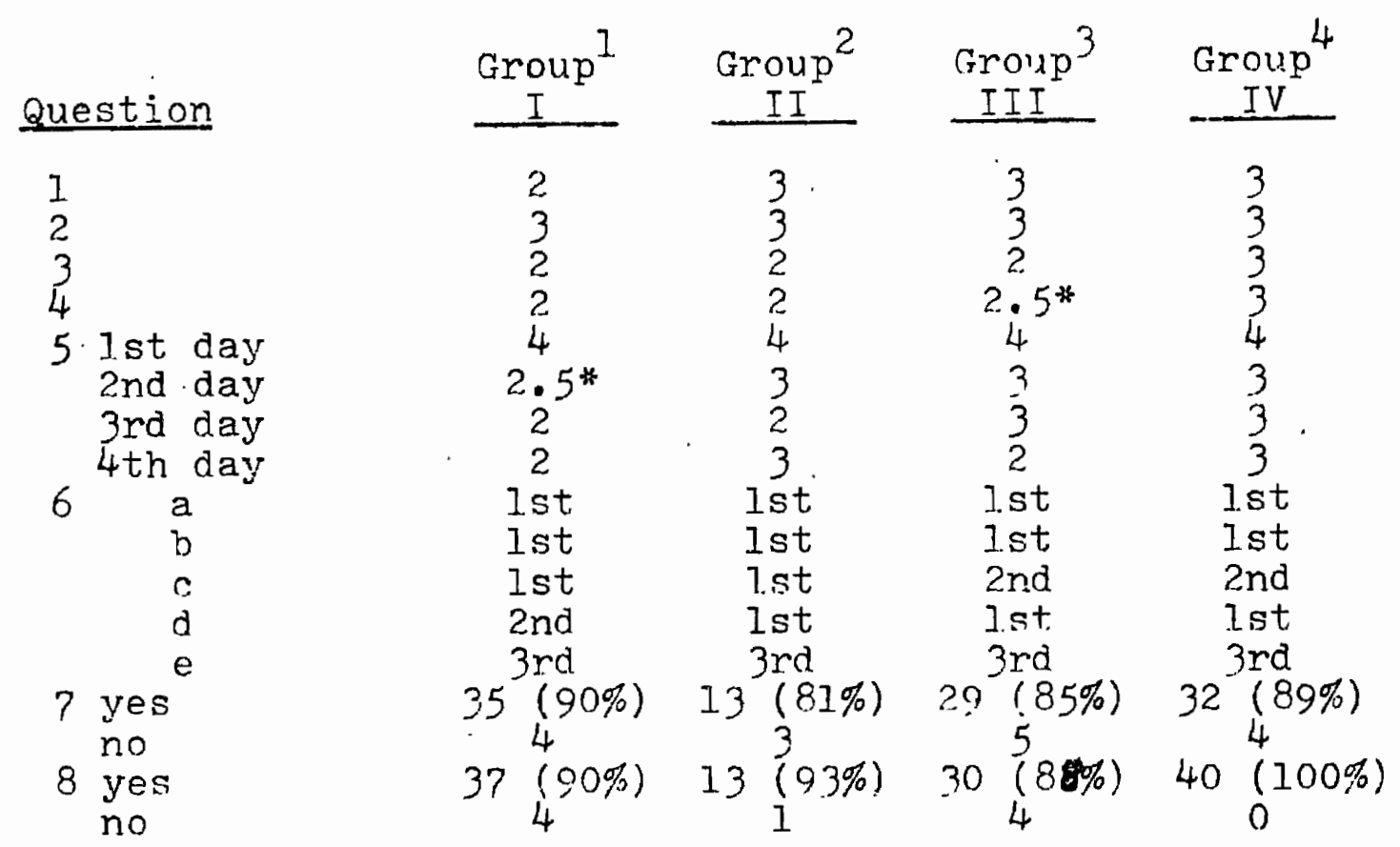

Notes: Questions:

1. The workshop itself

2. Time, pace and scheduling

3. Participating and interest of others

4. Interdisciplinary approach

5. Subject:

Ist day -- what i.t means to be aging

2nd day -- team approach to care

3 rd day -- social components of care

4th day -- special topics

6. Which day did you find

a. most interesting

b. most informative

c. most sensitizing

d. most practical for work

e. least stimulatine

?. Did you think cost of the workshop reasonable?

8. Has this been a worthwhile experience for you?

* Average of more than one mode

$1,2,3,4$ see Tables 1 and 2 
found the first day the most int resting and irformative, as well as excelient for rating. Workers outside the ir stitutions found the socond ciay t, be most sensitizingr-unlike those insjde the facilities; but nursine home steffs providing social services wer alone in finding the second day most practical fon work. There was overwhelming arr ?ement as to the reasonableness of lihe oroject's cost to participants, and as a worthwhile experience.

In Table 4, there was great varation in responses netween occupational groups to differınt methods of teachi ig, as well as varjations withir. the c upaticnal groups to different methods of teachine; and variations within the occupational groups to diffe-ent experiences with the same teaching methods. The latter, no doubt, reflect the effect of the personaljty and individual skills of the different teachers using the same meth ods.

Althougr. effect on skills wes included in the rating scheme for teaching methods, it was not expected to be relevant on the evaluation (Form 3) in general. The responses were erratic -- possibly for several reasons: during the organized groups of the second hay, leaders varied in skill, 
TART: 4

AVERAGED MODIT EFPFITS, "ROM O (NONE) TO 4 (MTOH), OF TEACHING MFHODS DY OCCUPATION CIASS

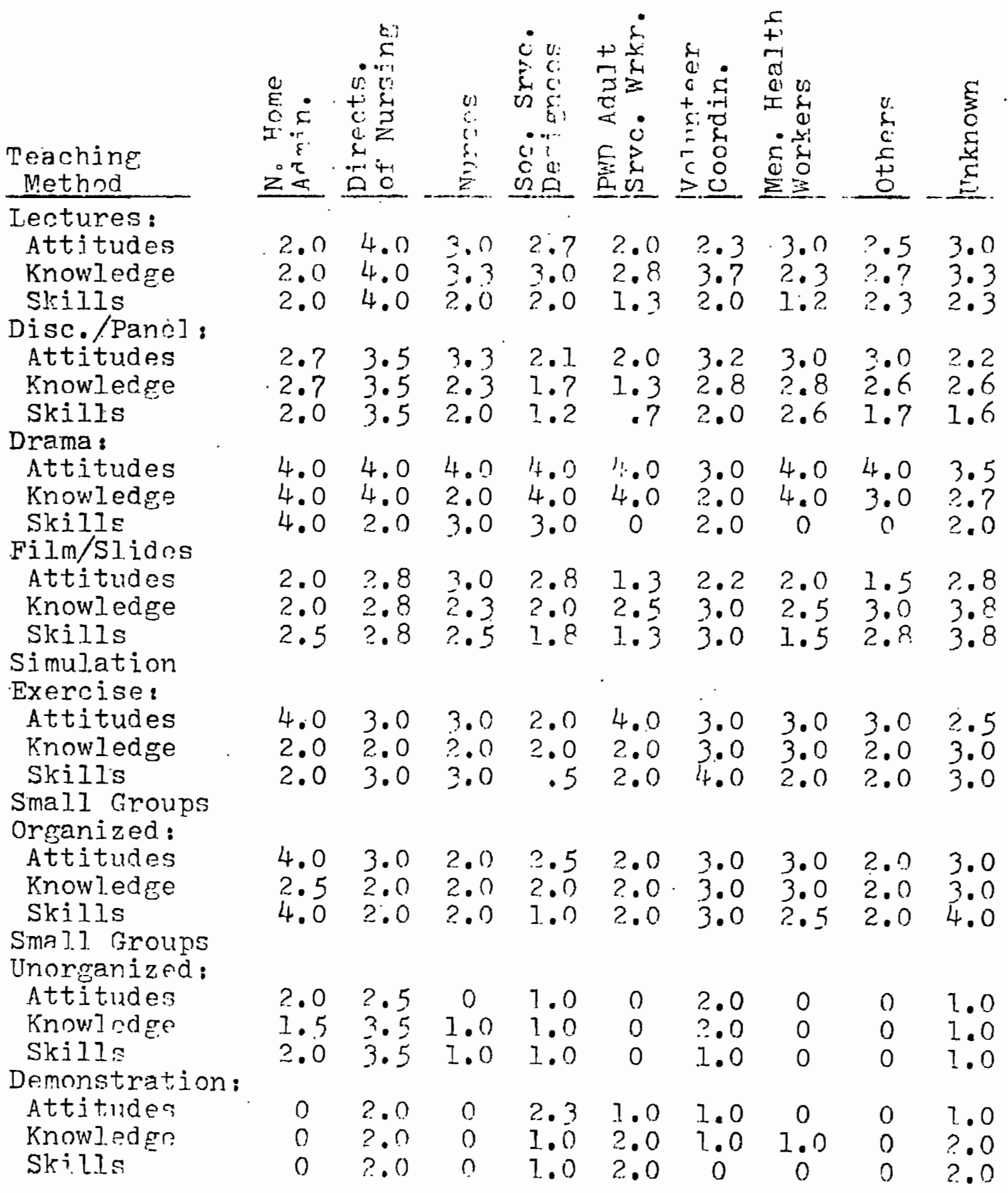


and the groups varied as to constituency (despite structuring them ahead of time as to occupational class, geographical area, etc.) Also, many participants may not have seriously differentiated between attitudes, knowledse and skills. A pattern was apparent in regard to the drama presentation and the dance demonstration: the first rated highly across the board while the latter rated very low -- reflecting again the quality of the performance. Totalling, in Table 5, the overall modal response to the teaching methods of the workshop, it is apparent that the respondents considered that they were most affected in areas of knowledge, then attjtudes, and less in skills. The lectures (despite the variation in speakers) and drama presentation were considered most effective in affecting knowledge. Films, simulation exercises and organized groups (with trained leaders) were more successful with skilllearning -- as could be expected. The unorganized small groups rated very low in all three learning areas. The discussion/panels, drama, films, small organized groups and simulation exercises were successful in affecting attitudes and so were the lectures. 
TABIE 5

UNWEIGHTED MEANS OF MODAL RATINGS OF EFFECTS

OF TEACHING METHODS, ALI. OCCUPATION CLASSES GROUPED TOGETHER

$\begin{array}{lccr} & \text { Attitudes } & \text { Knowledge } & \text { Skills } \\ \text { Lectures } & 2.72 & 3.01 & 2.12 \\ \text { Disc./Panel } & 2.78 & 2.47 & 1.92 \\ \text { Drama } & 3.83 & 3.07 & 1.78 \\ \text { Film/Slides } & 2.27 & 2.66 & 2.44 \\ \text { Simulation Exer. } & 3.06 & 2.33 & 2.39 \\ \text { Small Groups - } & & & \\ \text { Organized } & 2.51 & 2.39 & 2.50 \\ \text { Small Groups.. } & & & 1.06 \\ \text { Unorganized } & .94 & 1.11 & .78 \\ \text { Demonstration } & .81 & & \end{array}$


Table 6 indicates the specific areas, by occupatinnal class, in which skill improvement occurred. The category involving training techniques received the most mention, with particular emphasis on the simulation exercises, and especially the blind-walk. Many participants, in being led (with closed eyes) about the large, strange room full of unfamiliar objects in a disorganjzed pattern to get coffee and be fed some pastry, experienced new feelins of dependency and uncertainty. The other exercises -- such as lying prone on the floor (as in bed) -- helped to provide a different perspective for viewing one's world and environment. Nursing home administrators especially seemed to appreciate the value of such experiences as training techniques for their institutions.

Next, quantitatively, came improved ability to work in an interdisciplinary, team approach. On the second day, several hours were spent in staffing some vignettes (produced on video tapes with the help of professional actors) depicting common behavioral disability/problems of oldsters. Groups organized with members from different disciplines practiced staffing the cases. Many comments attested the 
TABTE 6

NUMBER OF DIFFERENT IMPROVEMENTS TN SPECIFIED SKIIL AREAS BY OCCUPATIONAI CIASS

\begin{tabular}{|c|c|c|c|c|c|}
\hline Dccupational & Class & $\begin{array}{l}\text { Tne. } \\
\text { Terh- } \\
\text { niques }\end{array}$ & $\begin{array}{l}\text { Working } \\
\text { with a } \\
\text { Team }\end{array}$ & $\begin{array}{c}\text { Communi- } \\
\text { cation } \\
\end{array}$ & $\begin{array}{l}\text { Wor'ing } \\
\text { with } \\
\text { Groups }\end{array}$ \\
\hline N. Home Adm & inis. & 1.3 & 6 & 5 & 1. \\
\hline Direct. of & Nurses & 0 & $I$ & .1 & 0 \\
\hline Nurses & ' & 4 & 1 & 2 & 1 \\
\hline Soc. Srv. D & esignees & 3 & 0 & 0 & 1 \\
\hline PWD AduIt S & rve. Wrkr. & 4 & 9 & 6 & 1 \\
\hline Volun. Coor & dinator & 3 & 1 & 0 & 2 \\
\hline Ment, Healt & $h$ Hrkr. & 3 & 2 & 1 & 0 \\
\hline Other & & 4 & 1 & 4 & 0 \\
\hline Unknown & & 1 & 0 & 0 & 0 \\
\hline Totals & & 35 & 2.1 & 19 & 6 \\
\hline
\end{tabular}


value of contributions made from such a broad diversity of workers.

Communication skills were devoloped by practicing alternative ways of interviewing, and new ways of examining relationships -- in small groups.

The interaction and nature of the group experiences on the second day as comparnd with the third day was genera]ly noted to be different: those of the second day were organized ahear of time and training provided for the leaders. Positive experjennes in group process were noted in the second day activities, and thejr absence, generally, in the third day. 


\section{CONCLUSIONS AND IMPLICATIONS}

This section will focus on the following subjects in the order presented here: workshop design, the evaluation models, conclusions fr $2 \mathrm{~m}$ analyzing the data, and implications for future workshops.

Because of the nature of the target group (invited participants), the effects of the training appear to be diverse. By planning for a large, heterogeneous group of trainees, more resources were available for bringing in highly skilled and expensive teachers, a wider range of subjects was presented, and yet $n$ st in the depth that would have been possible with a smaller, more homogenous group of participants. Starting with the fact that little, if any, systematic training had been done with Public Welfare workers providing social service to clients in nursing homes in the state, and the recognition that a preponderance of nursing home residents are welfare clients (and more so in the poorer, more inadequate facilities) the need for including such persons seemed obvious. Since the workshop was to focus on upgrading social service, and little had been previously done in training any nursing home personnel in this area, that need appeared obvious also. So not only were different occupational groups brought together, but those with different interests, motivations and goals as well. 
They came from both urban and rural areas of the state, with considerable differences in community and technical resources, education and experience.

Becuase of the requirement for 32 hours of training in the contract between the sponsoring agencies, and the distances many of the participants had to travel to attend, a great deal was packed into the four days. Some days had more variety in teaching methods than others.

Two different approaches to evaluation were. used. One required that the explicit listings of numerous items be rated from 0 to 4 . A specific list of subjects was itemized for consideration in areas of learning, program content and teaching modes. The other model utilized a continuum from weak to strong $(0$ to 60$)$ upon which each participant selected a position indicating an estimate of his expertise regarding several broad subject areas both at the beginning and again at the end of the training project.

The first evaluation model seemed superior to the second. Although clear communication at best is never easy, at least the different components being addressed seemed more definitive and specific. The areas were much more general in the second model, with greater room for subjectivity and vagueness of definition. Some participant groups apparently lost or decreased their knowledge in some subject areas in terms of their positions on the continuum at the end of the training. They most likely misestimated their beginning 
position, and came to rate themselves lower in the light of the workshop experience afterward. Others, no doubt, came to the training projert with a high, sophisticated level of knowledge and skills snd had little to show as gain in those areas, regardless of which kind of evaluation models were used.

In analyzing the data, results fall into two general categories, impact of knowledge in specific areas, and effectiveness of different teaching methods.

There was a satisfactcry percentage of returns on the long evaluation forms, $84 \%$ of those given out. The four basic divisions of participants offered an insightful means of comparing the results, all were in positions to promote or provide social service, directly or indirectly, to clients in nursing homes, from within or without the facility. Groups \#1 and \#2 were from within the institutions: \#1 as provider of social service and \#2 was not. Groups \#3 and \#4 were from outside long term care facilities: \#3 was provider of social service to residents within the facility, \#4 was not.

In general, it appears that the participants who work outside the institutions learned the most about "the nursing home," "what it means to be an aging person" and "meeting needs within the institution:" staff from within the institutions learned more about social services, and the pattern was mixed regarding community resources. 
The overall rating of the workshop was at level 3 (between good and excellent) by Groups \#2, \#3 and \#4; it was rated at level 2 (good) by Group \#l. Those working outside nursing homes found the simulation exercises and small groups of the second day the most sensitizing -- perhaps becuase of their relative apartness from the facilities and old people -- compared to nursing home personnel. In the different kinds of skill improvements listed by some participants, it was interesting to note that nursing home administrators attached importance to training techniques, and welfare workers picked out "working as a team" more than other groups of participants. There was some indication that the participants found other methods of teaching -such as the lectures or drama -- had impact on their skill level, along with the simulation exercises and small group activities. The impression was also received that some workers did not distinguish between attitudes, knowledge and skills.

Nursing home administrators were much affected in attitudes by the drama presentation, simulation exercises and small groups; they rated most of the teaching methods to be of average effectiveness in transmitting both knowledge, except for the drama again (which was rated high), and skills, except for the small groups (rated high also.) Nurses (including the Directors of Nurses) found the lectures and drama highly effective on attitudes and knowledge, and in general rated all the teaching methods more highly 
than did the administrators. The Public Welfare workers, volunteer coordinators and mental health workers all found the simulation exercises affected their attitudes considerably. These general reactions could reflect different values, training and personal experience in their professional roles.

The efficacy of using a variety of teaching modes was indicated by the "above-average" rating for effectiveness of al] the methods used except the unorganized small groups and the dance demonstration. Most likely, the low scores for these two events reflected a general lack of impact because of the low level of the teaching performance -- apart from the mode itself. Many such comments were so written on the evaluation forms.

An important implication for future practice for this kind of a training project would be the value of serious analysis of the goals desired and an assessment of the level. of sophistication of the intended participants. The workshop was rated worthwhile, and generally considered successful, despite the heterogeneity of the target group. The social interaction of different occupational groups also was considered to be desirable. The large numbers of people made it harder to handle the numerous small groups in an informal, intimate fashion, but the large audience no doubt was a stimulus for lecturing and the dramatic presentation. The value of changing pace, structure and teaching 
methods was made obvious by comments on the evaluation forms comparing the days whon this was done with those when it wasn't done. Physice L activity and mental/emotional activities appear to be closely related, and a variety of instructors, group sizas, methods, etc., within limits, are an aid to learning.

The value of having a dynamic, outstanding keynote speaker is great for "turning people on" in an exciting way: it also may make those who follow a bit pale in comparison. Finally, this evaluation of the workshop, Bridges, is only approximate at this point, due to time limitations. Further inferential analyses of a more sophisticated nature, in the near future, will produce a more definitive, detailed and conclusive evaluation. 


\section{BIBLIOGRAPHY}

The Advorate for Human Services, NASW Questions N. H. Socia] Workers, Isegislative News attor, Washington, D. r., oct. 31, 1973, Nov. 20, 1973.

Burr, Helen Turner, The Nature of Mental Tmpairment in the Aged in Challenges Facing Seninr Citizens in the $1970^{\prime}$ s, National Council on Agine Conference of Senior Citizens, Washington, D. C., 1969.

Burr, Hol en Turner, Psychological Aspects of Aging, 3rd ed., (Springfield, III.: Thomas Publjshers, 1971.).

Burr, James J., Protection Services Project for 0lder Adults, (Washington, D. C.: D.H.E.W., Community Services Administration, 1.971).

Butler, Robert N., "Concerning Decent Institutional Care," in Proceedings of Conferences, Gerontological Society (Washington, D. D.: D.H.E.W., N.T.M.H., 1972).

Goffman, Erwing, Goldford, Alvin I., et al, Death Rate of Relocated Nursing Home Residents in D. P. Kent, 3rd ed. ((Chicago: Eldine Press, 1962).

Goldford, Alvin, and Turner, Helen, "Psychotherapy of Aged Persons: Utilization and Effectiveness of 'Brief' Therapy," American Journal. of Psychiatry, Vol. 109, No. 12, June, 1963.

Gossett, Helen, Curricul um for Social Services in Long-Term Health Care Facilities, mimeo (Washington, D. D.: N.A.S.N., 1972).

Harper, Bernice C, and Brown, Henry J., Socjal Services in Extended Care Facilities: Blueprint for Action (California: University of California Extension, 1968).

Jennings, Nancy S., "It's Our Last Chance to Do Something for Geriatrics," Nursing Care, Vol. 7, No. 2, February, 1974, pp. 28-32.

Kosberg, Jordan J., "The Nursine Home: A Social Work Paradox," Social Work, vol. 1., , No. 2, March, 1.973, pp. $104-110$. 
Mental Health: Princinles and Training Techniques in Nursing Home Care (Washington, D. C.: D.H.E.W. Publication No. 73-9046, N.I.M.H., 1972).

Stofsky, Bemard, The Nursing Hoine and the Aged Psychiatric Patient, Appleton-Cushing, Conference, 1970.

Sydnor, Gajil Olmstead and Wold, Patricia Mears, Some Correlates of Morale Amnng Nursing Home Residents, Practicum, Portland State Injversity School of Social Work, 1974 .

Turner, Helen, Persona]ity Functionine in Later Life: Implicatinns for Practice in Planning Welfore services for Older People (Washington, D. C.: D.H.F.W., Bureau of Family services, 1966). 
THIS IS A THIRTY-TWO HOUR TRAINING PROJECT FOR THE PURPOSE OF IMPROVING SOCIAL SERVICES, CONSULTATION AND PLANNING IN LONG TERM CARE FACILITIES. IT IS: MADE POSSIBLE THROUGH A CONTRACT BETWEEN THE NATIONAL ASJOCIATION OF SOCIAI WORKERS, INC.., AND THE HEAITH RESOURCE ADMINISTRATION OF THE DEPARTMENT OF HEALTH, EDUCATION AND WELFARE: PROJECT PROVIDE.

APRIL $3-4$ and $16-17,1974$

Thunderbird Motel, Janzten Beach, Portland, Oregon

\section{IT IS SPONSORED BY:}

Oregon Chapter, National Association of Social Workers and

Oregon State Mental Health Division and Oregon Health Care Association

Profect Coordinator \& Facilitator: Corrinne Williams, Oregon Chapter, National Assoc. of Social Workers

Project Planning Consultant: Glen Dugger, Medicaide Services Consultant, Oregon Mental Health Division 
Life can only be understood backwards, but it must be lived forwards.

-.- Kierkegaard

\section{PROGRAM}

Wed., Apr. 3rd: WHAT IT MEANS TO BE AN AGING PERSON

8:15 am Registration

9:00 Welcome and Introductions:

John Hale, President, Ore. Ch., N.A.S.W.

Braxton Warner, Director, Project Pro-

vide, N.A.S.W., washington, D.C.

Cliff Becker, Consultant, Region 10,

H.E.W.

Michael Kopcho, Coordinator, Public

Health Adm., Region 10, H.E.W.

9:15 Building Bridges:

Ruth Hocks, Ombudsman to Nursing Homes

Dr. J. D. Bray, Ore. Mental Health Div.

Andrew Juras, Ore. Public Welfare Div.

- Dr. Edward Press, Ore. Health Div.

John Richard, Ore. Health Care Assoc.

10:00 The Evaluation Process:

Corrinne Williams, Project Facilitator

10:15 Coffee Break

10:30 Theatre of Feast

Alberto Cereghino, Director

10:45 Consultation as a Bridge:

Alice Collins, M.S.W. Consultant, Author

12:00 Lunch; Riverview Ballroom

1:15 pm Being old in America:

Dr. Carl Eisdorfer; introduced by Dr: John o'Brien, Institute on Aging, P.S.U.

2:15 A Discussion with Dr. Eisdorfer

Panel of Senior Citizens

2:45 Break

3:00 The Dramatic Experience of Being old Theatre of Feast

4:00 Announcements

- Dr. Eisdorfer's presence is made possible by a grant from the Ore. Mental Health Div. 
wed., Apr. 3rd continued

4:45 pm No-host Cocktail Hour

6:00 Dinner, Riverview Ballroom

7:15 The Growth, Development and Adjustment of Older Persons:

Dr. Carl Eisdorfer, introduced bv Glen

Dugger, Ore. Mental Health Div.

8:15 Evaluation

Thur., Apr. 4th: THE TEAM APQROACH IN NURSING HOME CARE

8:30 am Reqistration

9:00 Meetings of Assigned Groups

9:10 Film: Home for Life

10:15 Communication and Interaction, Simulation Exercises, Aqe Regression and Age Proqression:

Dr. Jim Lurie

12:00 Lunch, Riverview Ballroom

1:15 pm Vignettes on video-tapees depicting behavioral problems of the elderly; staffing exercioes:

Dr. Jim Lurie

2:30 Break

2:45 Programing and Feedback

$3: 45 \quad$ Evaluation

VISITING FACULTY:

Dr. Carl Eisdorfer is Chairman of the Psychiatry Dept., Univ. of Wash. School of Nedicine

Dr. Huch James Lurie, Asst. Prof. of Psychiatry and Coord. of Continuing Educ. in Psychology, Univ. of Wash. School of Wiedicine 
Life can only be understood backwards, but it must be lived forwards.

-- Kierkegaard

\section{PROGRAM}

Wed.2, Apr. 3rd: WHAT IT MEANS TO BE AN AGING PERSON

Thux., ApE. 4th: THE TEAM APPROACH IN NURSING UOME CARE

Tue.e. Apr. 16th:

8:15 am Registration

SOCIAL COMPONENTS OF NURSING HOME CARE Dr. Theodore Koff

9:00 Impact of the Environment on the Patient Milicu Therapy Coffee Break

Personal Identity and Aging

1:00 pm Lunch, Riverview Room

2:15 Social Needs of the Staff in Institutions

$3: 30 \quad$ Break

MENTAL RETARDATION \& DEVELOPMENTAL DISABLEMENT

3:45 Services and the Role of the Service Coordinator:

Ben Arthur, Specialist, Support Services, Mental Health Division

Activity Center Services:

Barbara Place, Director, Me Re Activity Center, Gresham, Oregon

Leisure Time and Self Help Skills:. Staff of Fairview Hospital \& Training Center Barbara Lyon - Program Coordinator Shirley Squires - Training Assistant Loran Tomblinson - Traininq Assistant 
$5,45 \mathrm{pm}$ No-host Cocktail Hour

6:30 Dinner, Riverview Room

Geriatric Dance Therapy Demonstration:

Karen Irwin, Dance Therapist

Evaluation

Wedow Apr. 17th: SPECIAL. TOPICS:

. 8 =I5 an Registration

9:00. The New Law on Involuntary Committment of Mentaliy III Citizens:

Myron B. (Mike) Katz, Chairman, A.C.L.U.. Committee on Involuntary Committment

10:00 Coffee Break

I0:I5 New Standards and Regulations for Skilled Nursing Homes:-

Michael Kopcho, Coordinator, Public

Health Administration, Region 10, HEW

10:25 Community and Volunteer Services::

Eugene Bui, Coordinator, Multnomah County Board of Commissioners

Jo Roughton, Volunteer Coordinator, Iinn County Public Welfare Division

- Father Peter Paulson, Director, Northwest Pilot Project, Portiand

12:00 Lunches:

O.H.C.A. - Business Meeting

Workshop - A Model for Consultation Bobbie Hyerstay, Outreach Team Leáder,

Lane County Mental Health Program

2:15 pm The Use and Misuse of Psychotropic Medicines:

Dr. George Larimer, Staff Psychologist, Multnomah County Office of Probation and Parole

3:.15 Evaluation

3:30 Tying It All Together

VISITING FACULTY: Dr. Theodore Koff, Educator and

Executive-Director, Handmacher Jewish Nursing

Home, Tuscon, Arizona 
On behalf of the Ofegon Chapter of the National Assoc. of Soclal Workers and myseif, we wish to express our appreciation to the following individuals for their help in producing this workshop:

THEATRE OF FEAST

AIberto Cereghino, Director

Sponsored by the Bureau of Human firesources, City of Portland

Actors and Actresses:

Camilla Dezell

Gladys Tippett

Elsa Soeling

Mary Smith

Peggy Battaglia

Sally Kuhlkin

George True

Dottie Carte

Margaret Leach

Janet $K$. Smith

CONEERENCE STAFF

Patricia Wold

J111 Sydnor

Kathy Mitcheli

Marilyn Nolan

GROUR FACILITATORS

John Hale

Ada wilson

Mike Kopcho

Cliff Becker

Roger Olson

Ursuda Tabor
Audrey Mathews
Nancy Mancini
Charles Smutz
Ted Lupper

Bobbie Hyerstay

Camie Brown

Coeta stewart

Betty Yockey

Peter Paulson

AD HOC AND STEERING COMMITTEES' MEMBERS

Betty Hands, State Program on Aging Bertha Roth, Dept. of Human Resources

Lucille Pugh, Public Welfare Div., Adult Services

Helen Shirey, Public Welfare Div., Adult Services:

M.R. Arbuckle, Public Welfare Div., Medical Assist.

Helen Colburn, Salem Convalescent Center

Ruth Hocks, Nursing Home Ombudsman

John Hale, Pres., Ore. Ch., N.A.S.N.

John Richard, Ore. Health Care Assoc.

Eatriciai: Wold, P.S.U. School of Social Work

Shirley Coate, Kaiser Medical Care Program

Glen Dugger, Mental Health Div.

Clara Dawes, Public Welfare Div.

Mary Haight, East Multnomah Co. Public Welfare

Donna Wilkins, District Trainer, Public Welfare

Leonard Cain, PSU Institute on Aging

Ada Wilson, PSU School of Social work, Aging Prog.

Helen Philiips, Public Welfare Div., Medical Assist.

and Betty Leonard, Faculty, FSU School of Social Work, . for getting it all started. 
Part I

Form 1

Phase IA

$$
\text { WORKSHOP: BRIDGES }
$$

\section{(PROJECT PROVIDE)}

Training Program for Social Service Providers in Long-Term Care Facilities

1. SEX: _ Male _ Female 2. AGE:

3. ETHNIC ORIGIN : American Indian

- Astan American

- Black/Afro-American

4. PRESENT EMPLOYMENT Agency Auspice:

- Public

- Private Nonprofit

- Private profit

5. DURATION OF EMPLOYMENT

$$
\begin{aligned}
& \text { - Caucasian } \\
& \text { - Chicano/Mexican Amer. } \\
& \text { - Other }
\end{aligned}
$$

\section{Hours:}

- Full time ( 30 hrs. or more per week)

Part time (less than

30 hrs. per week).

\section{No. years with present employer:}

Under 2 yrs.

- At least 2 but under 6 yrs.

- At least 6 but under

10 yrs:

No. years in present position:

- Under 2 yrs. _- At least 10 but

- At least 2 but under 6 yrs.

At least 6 but under 10 yrs.
At least 10 but

unider 20 yrs.

over 20 vrs. under 20 yrs.

Over 20 yrs.

6. What is your primary professional background?

7. What is your present position?

$$
\begin{aligned}
& \text { Nurs. Home Administrator } \\
& \text { - Nurse - RN Lirector of Nurses } \\
& \text { - Mental Health worker }
\end{aligned}
$$

8. Are you also responsible for the social services
in a long term care facility?

9. If part of nursing home staff, what is the size of your facility: no. of beds

10. How did you learn about this training program?

$$
\begin{array}{ll}
\text { Via employer } & \text { Mailed publicity } \\
\text { - NASW Chapter } & \text { Mass media } \\
\text { - Other organizations } & \text { - Word of mouth }
\end{array}
$$


Place an $X$ anywhere along the line as it represents the level of expertise you feel that you have in each of the areas of social services practice in nursing homes as described below.

\section{A. The Nursing Home}

The nursing home as the setting and instrument for meeting health-related social needs of its patients: the legal, community, economic and administrative factors; patient and family characteristics; and program elements affecting the facility's operation, its service, and its effectiveness in meeting social needs.

\section{very}

strong

very

weak

B. Perceptions of Soctal Service

Social services as seen by the regulatory agency, administrator, Social Work Consultant, social service designee, patient, family and consumer public: the strictures, functions, viewpoints of each which affect what social needs are recognized, understood and met; achieving a comprehensive understanding of the total person.

\begin{tabular}{lr}
\hline very & very \\
strong & weak
\end{tabular}

C. What it Means to be an Aging Person

Physical and mental aspects; social impairments; behavioral, psychological, emotional impact of impairment; use of experiential exercises; development of empathy with the patient.

\section{very}

strong

very

weak

D. How to Meet the Needs of Aging Persons Within the Institution

Methods for assessing social service needs of individuals, their emotional states, mental and physical integrity; and techniques for improving their functioning. 


\section{E. Resources Within the Community}

inking the nursing home with the continuum of health care programs; IncreasIng the use of non-LTCF-based resources for patients, and strengthening the LTCF as a communtty resource. 
4. Rease rate how much you have learned in this workshop in the following areas (check 1 of the 5 boxes):

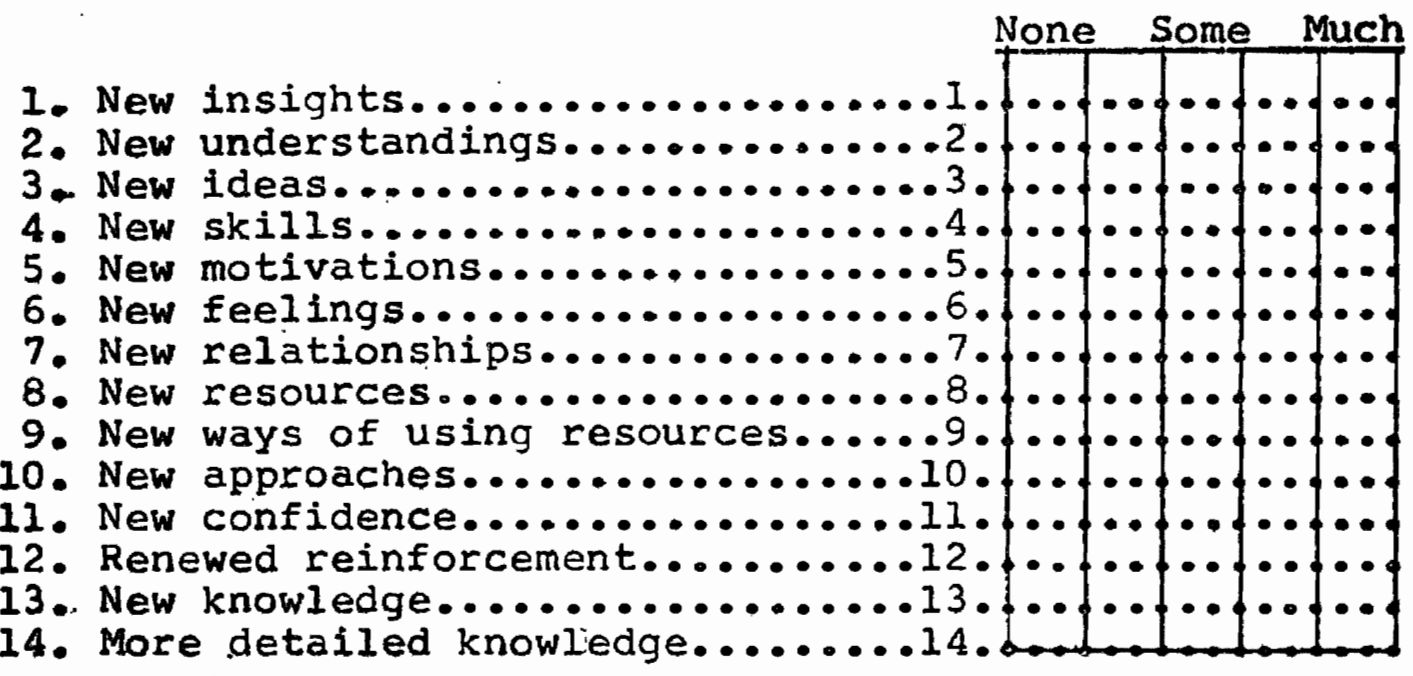
e.g.

B. Please rate the following aspects of the 32-hr. program:

1. The workshop itself.

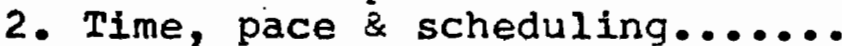

3. Participation \& interest of

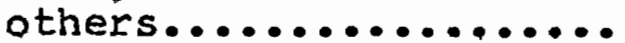

4. Interdisciplinary approach...

5. Subjects:

Ist day - what it means to be

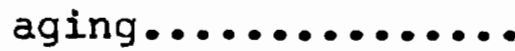

2nd day - team approach to care

3rd day - social components of

4 th day - special

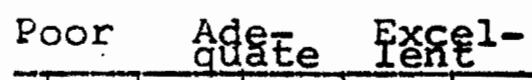

6. Which day did you find:

most interesting........

most informative..........

most sensitizing ..........

most practical for work..

least stimulating........

7. Did you think the cost of the workshop reasonable? -yes _no

8. Has this been a worthwhile experience for you? _yes no 
Phase IB

1. Place an $X$ anywhere along the line as it represents the level of expertise you feel that you have in each of the areas of social services practice in nursing home:s as described below.

A. The Nurs ing Home

The nursing home as the setting and instrument for meeting health-related social needs of its patients: the legal, community, economic and administrative factors; patient and family characteristics; and program elements affecting the facility's operation, its service, and its effectiveness in meeting social needs.

\section{very}

strong

very

weak

B. Perceptions of Social Service

Social services as seen by the regulatory agency, administrator, Social Work Consultant, social service designee, patient, family and consumer public: the strictures, functions, viewpoints of each which affect what social needs are recognized, understood and met; achieving a comprehensive understanding of the total person.

\begin{tabular}{ll}
\hline very & very \\
strong & weak
\end{tabular}

C. What it Means to be an Aging Person

Physical and mental aspects; social impairments; behavioral, psychological, emotional impact of impairment; use of experiential exercises; development of empathy with the patient.

\begin{tabular}{ll}
\hline very & very \\
strong & weak
\end{tabular}

D. How to Meet the Needs of Aging Persons Within the Institution

Methods for assessing social service needs of individuals, their emotional states, mental and physical integrity; and techniques for improving their functioning.

\begin{tabular}{lr}
\hline very & very \\
strong & weak
\end{tabular}


E. Resources within the Community

Linking the nursing home with the continuum of health care programs; increasing the use of non-LTCF-based resources for patients, and strengthening the LTCF as a community resource.

\begin{tabular}{lr}
\hline very & very \\
strong & weak
\end{tabular}

2. Overall assessment of the quality of the subject matter chosen:
II Excellent
$\triangle 1$ Good
II Fair
IT Poor

3. Overall assessment of the quality of teaching:
II Excellent
II Good
I Fair
II Poor

4. Assessment of the training program planning (e.g., times selected, piace selected, physical setting, etc.)
LI Excellent
II Good
I Fair
$\mp$ Poor

5. What subject matter was taught best?

6. What subject, if any, was not included in which you are particularly interested? 
Phase IB

$$
-3-
$$

7. What was the most important thing you learned as a result of this experience?

8. General comments on this training program (or this nosy questionnaire): 
Fiease rate the following modes of teaching, if applicable, in terms of affecting your attitudes, knowledge and skills during today's session. (Check ' $I$ of the 5 boxes.)

1. Lectures

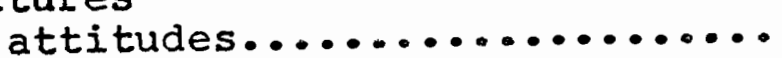
knowledge.................

2. Discussion/panel groups

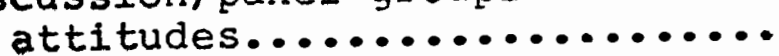

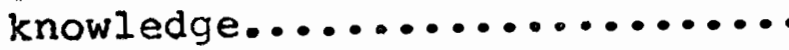
skilis....................

3. Dramatic presentation

attitudes knowledge skil1s

4. Film/slides attitudes knowledge ski1.s

5. Simulation exercises attitudes. knowledge skills.

6. Small group activities attitides................... knowieilgค................. skilis

7. Demonstration (dance therapy)

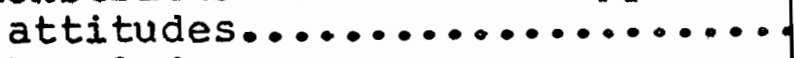

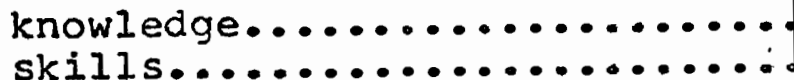

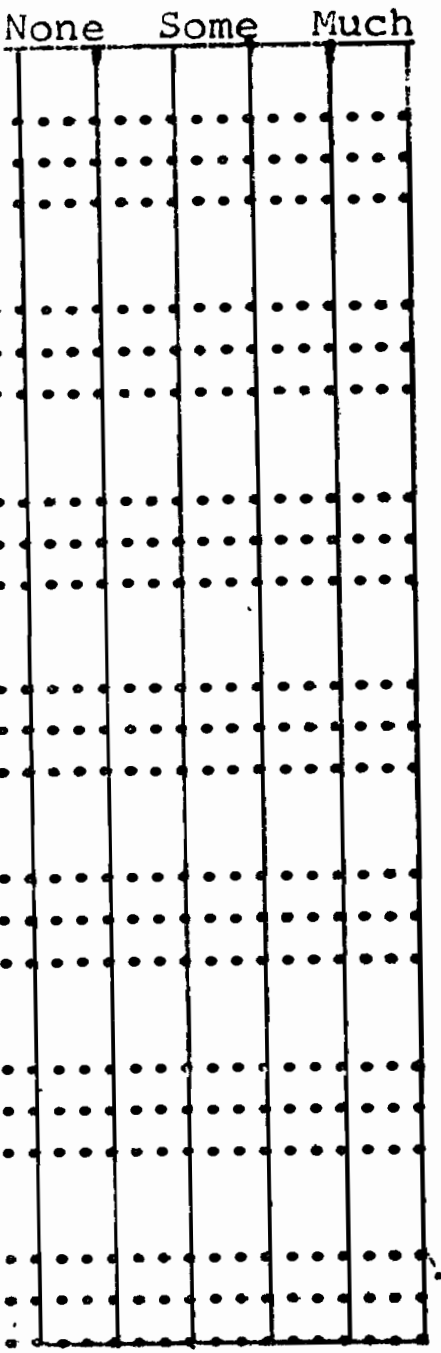

8. Would you specify any particular skill that you acquired or improved in today's session that will change your way of working with people from now on:

PIease check present position: Nursing Home Consultant

- Nursing Home Social Service Designee

- Nursing. Home Administrator

- Nurse _. Director of Nurses

- Adult Service Norker/Supervisor, PWD

- Volunteer Coordinator

- Mental Health worker

Date: April ..3rd _...4th _ 16th ....17th 